\section{Rootstock Improves High-tunnel Tomato Water Use Efficiency}

\author{
David H. Suchoff ${ }^{1,5}$, Jonathan R. Schultheis ${ }^{1}$, \\ Matthew D. Kleinhenz ${ }^{2}$, Frank J. Louws ${ }^{3,4}$, and Christopher C. Gunter ${ }^{1}$
}

ADDITIONAL INDEX WORDS. grafted tomato, herbaceous graft, irrigation, heirloom tomato, on-farm, fruit yield, economic analysis

SUMMARY. The following study was conducted to address water use efficiency in grafted tomato (Solanum lycopersicum) in an on-farm environment. The commercial rootstock cultivars Beaufort (BE) and Shield (S) were chosen as these two have different root system morphologies that may benefit water use efficiency. The heirloom cultivar Cherokee Purple (CP) was grafted onto both rootstocks and used as the nongrafted control. The study was conducted in 2016 and 2017 on a 5-acre vegetable and cut flower farm in North Carolina's Piedmont region. Plants were grown under protected, high-tunnel culture where they received either $100 \%$ (3 hours every other day) or $50 \%$ ( 1.5 hours every other day) of the grower's normal irrigation regime. At 50\% irrigation, 'Beaufort'-grafted plants yielded significantly more than nongrafted 'Cherokee Purple' and 'Shield'-grafted plants. Furthermore, 'Beaufort'-grafted plants at $50 \%$ irrigation yielded more than nongrafted 'Cherokee Purple' receiving the $\mathbf{1 0 0 \%}$ irrigation treatment. The 'Beaufort'-grafted plants significantly improved irrigation water use efficiency (iWUE) at the $50 \%$ irrigation treatment compared with the other graft treatments. Yield and iWUE of 'Shield'grafted plants were comparable with the nongrafted 'Cherokee Purple' at both irrigation treatments. Regardless of irrigation treatment, grafting onto 'Beaufort' improved the quality of total fruit harvested. An economic assessment was conducted to determine the feasibility of using grafted plants in conditions lacking significant disease pressure. Purchasing grafted transplants would increase the initial investment by \$5227.2 per acre. However, the increased yield obtained when using 'Beaufort' rootstock at $\mathbf{5 0 \%}$ irrigation increased net revenue by $\$ 35,900.41$ per acre compared with nongrafted 'Cherokee Purple' receiving $100 \%$ irrigation, amounting to a $44.6 \%$ increase in net revenue while saving $\approx 383,242 \mathrm{gal} / \mathrm{acre}$ of water per growing season. These results indicate that growers can select rootstocks to better manage water use in an environmentally friendly manner without limiting economic gains.

$\mathrm{C}$ rop production systems must become more water use efficient. About $70 \%$ of global and $80 \%$ of the U.S. fresh water consumption is for agricultural practices (Evans and Sadler, 2008; Schaible and Aillery, 2012). With continual growth in global population, it is estimated that using current practices, water consumption for agriculture will increase by $70 \%$ to $90 \%$ by 2050 (Molden, 2007). With the

This material is based on work that is supported by the National Institute of Food and Agriculture, U.S. Department of Agriculture, under award number 2016-51181-25404

${ }^{1}$ Department of Horticultural Science, North Carolina State University, Raleigh, NC 27695

${ }^{2}$ Department of Horticulture and Crop Science, The Ohio State University, Wooster, OH 44691

${ }^{3}$ Department of Plant Pathology, North Carolina State University, Raleigh, NC 27695

${ }^{4}$ NSF Center for Integrated Pest Management, North Carolina State University, Raleigh, NC 27695

${ }^{5}$ Corresponding author. E-mail: dhsuchof@ncsu.edu. https://doi.org/10.21273/HORTTECH04015-18 depletion of many fresh water sources and the increasing uncertainty of rainfall due to climate change, continuous increase in agricultural water consumption is untenable (Food and Agriculture Organization of the United Nations, 2002). These challenges have many calling for a "Blue Revolution"the development of crops that can maintain or improve current yields while reducing overall water inputs (Pennisi, 2008).

Numerous cultural practices and breeding efforts have been aimed at improving water use efficiency. Practices that direct irrigation water to the plant roots, such as subsurface drip, or that mitigate surface evaporation can greatly improve water use efficiency by reducing water loss (De Pascale et al., 2011). Traditional breeding efforts for more water useefficient crops have shown mixed results. Many of the physiological plant responses associated with improved growth or maintenance at low water availability such as stomatal closure and reduced leaf area limit photosynthesis and consequently reduce yields (Blum, 2005).

Molecular approaches to improving water use efficiency show promise, but because of the complex network of genes associated with plant-water relations, few genetically altered crops show improved water use efficiency when grown in the field compared with controlled environments (Pennisi, 2008). Root systems, being the site of water uptake, have garnered substantial attention in the effort to improve water uptake and use efficiencies (Gewin, 2010; Lynch, 2007). Numerous root morphological and architectural traits such as diameter, length, and spatial distribution all affect water uptake under limiting conditions (Comas et al., 2013; Ho et al., 2005; Huang and Eissenstat, 2000; Mickelbart et al., 2015). Developing crops that contain both desired fruit and root traits through traditional breeding efforts is difficult because of the necessary time, challenges with phenotyping

\begin{tabular}{llll}
\hline $\begin{array}{l}\text { Units } \\
\begin{array}{l}\text { To convert U.S. to SI, } \\
\text { multiply by }\end{array}\end{array}$ & U.S. unit & SI unit & $\begin{array}{l}\text { To convert SI to U.S., } \\
\text { multiply by }\end{array}$ \\
\hline 0.4047 & $\mathrm{acre}(\mathrm{s})$ & $\mathrm{ha}$ & $2.471 \mathrm{l}$ \\
100 & $\mathrm{bar}$ & $\mathrm{kPa}$ & 0.01 \\
0.3048 & $\mathrm{ft}$ & $\mathrm{m}$ & 3.2808 \\
0.0700 & $\mathrm{ft}^{3} / \mathrm{acre}$ & $\mathrm{m}^{3} \cdot \mathrm{ha}^{-1}$ & 14.2913 \\
3.7854 & $\mathrm{gal}$ & $\mathrm{L}$ & 0.2642 \\
9.3540 & $\mathrm{gal} / \mathrm{acre}$ & $\mathrm{L} \cdot \mathrm{h}^{-1}$ & 0.1069 \\
2.54 & inch $(\mathrm{es})$ & $\mathrm{cm}$ & 0.3937 \\
1.1209 & $\mathrm{lb} / \mathrm{acre}$ & $\mathrm{kg} \cdot \mathrm{ha}^{-1}$ & 0.8922 \\
0.1198 & $\mathrm{lb} / \mathrm{gal}$ & $\mathrm{kg} \cdot \mathrm{L}^{-1}$ & 8.3454 \\
10 & $\mathrm{meq} / 100 \mathrm{~cm}^{3}$ & $\mathrm{mmol} \cdot \mathrm{L}^{-1}$ & 0.1 \\
0.0254 & $\mathrm{mil}$ & $\mathrm{mm}$ & 39.3701 \\
0.0749 & $\mathrm{oz} / 100 \mathrm{gal}$ & $\mathrm{g} \cdot \mathrm{L}^{-1}$ & 13.3526 \\
$\left({ }^{\circ} \mathrm{F}-32\right) \div 1.8$ & ${ }^{\circ} \mathrm{F}$ & ${ }^{\circ} \mathrm{C}$ & $\left({ }^{\circ} \mathrm{C} \times 1.8\right)+32$ \\
$\left({ }^{\circ} \mathrm{F} \div 1.8\right)+255.37$ & ${ }^{\circ} \mathrm{F}$ & $\mathrm{K}$ & $(\mathrm{K}-255.37) \times 1.8$
\end{tabular}


root systems, and low heritability of root traits (Malamy, 2005; Wasson et al., 2012). Molecular approaches to altering root system traits may be a quicker means, compared with traditional breeding, but public perceptions of genetically modified crops may hinder widespread acceptance. One new approach not involving genetic modification is through grafting.

Grafting susceptible scion cultivars onto resistant rootstocks is an effective means of managing many economically significant soil-borne pathogens that affect tomato (Louws

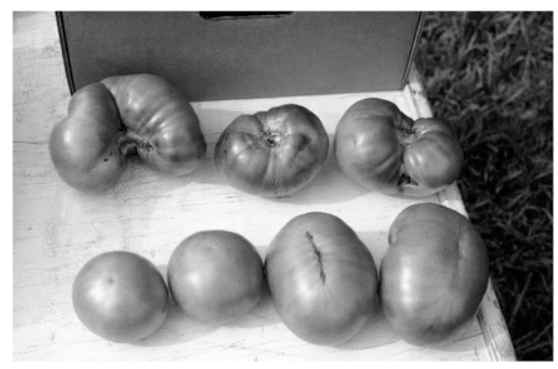

Fig. 1. Representative grade A (bottom row) and grade B (top row) tomato fruit based on the grower's specifications. Fruit grades based on the grower's specifications. Grade A fruit are those with no blemishes or disfigurement large than 2 inches $(5.1 \mathrm{~cm})$ in diameter. Grade B fruit are those with slight disfigurement, but still marketable, and culls are any nonmarketable fruit. et al., 2010). Although the main driver for grafting is the imparted resistance, numerous studies indicate that rootstocks may improve edaphic abiotic stress tolerance (Schwarz et al., 2010). Grafting the tomato cultivar Florida 47 onto either Multifort or BE rootstocks improved iWUE in a 2 -year field study (Djidonou et al., 2013b). The authors hypothesized that the improved iWUE may be attributed to changes in root system morphology (RSM) under stress. Root system morphoplasticity under stress can improve growth in limiting conditions; however, intrinsic root system morphological traits play a significant role in a plant's ability to efficiently use resources (Comas et al., 2013; Eissenstat, 1992; Henry et al., 2011). Both 'Multifort' and 'Beaufort' are interspecific hybrids (S. lycopersicum $\times$ Solanum habrochaites) and were shown to have similar root system morphologies that differed from 'Florida 47' (Suchoff et al., 2017). Whether the improved iWUE observed by Djidonou et al. (2013b) was due to differences in rootstock RSM is unclear. Furthermore, this study was conducted in an open field, controlled research facility setting. To date, no study has compared iWUE of grafted tomato in an on-farm setting. To address this, the following study was conducted to 1) Compare yield, growth, and iWUE of tomato grafted on rootstocks with differing RSM and

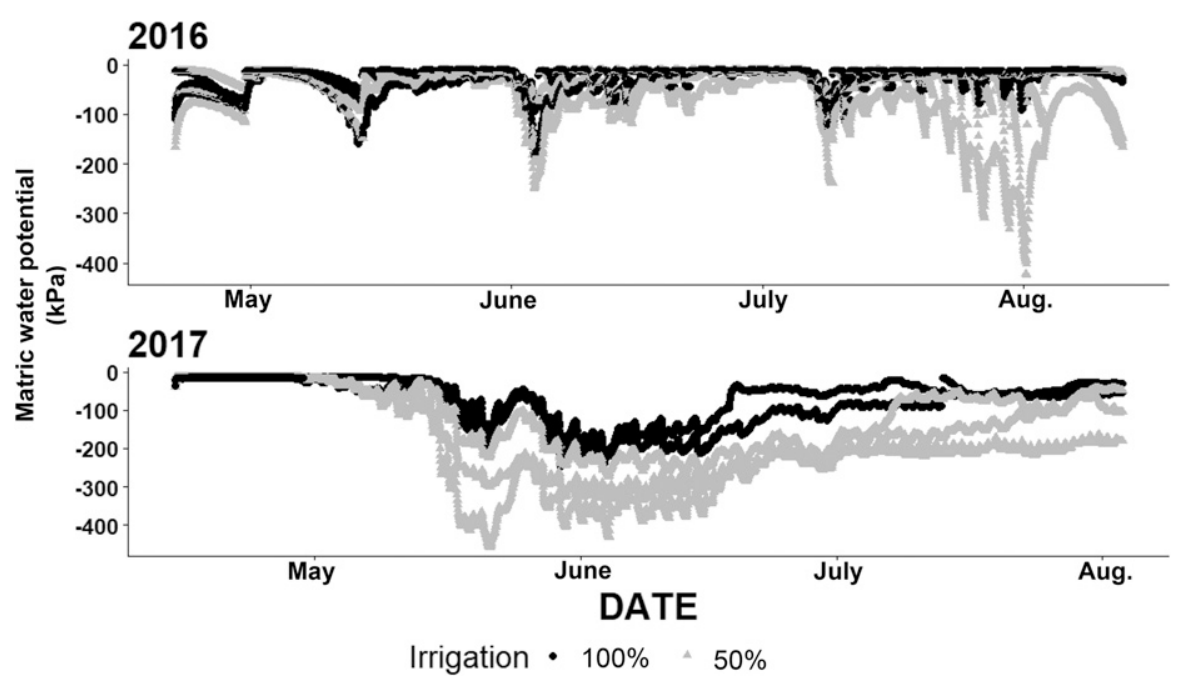

Fig. 2. Matric water potential of high-tunnel soils for two irrigation treatments of either $100 \%$ [ $3 \mathrm{~h}$ every other day $(14,741 \mathrm{gal} / \mathrm{acre})]$ or $50 \%$ [ $1.5 \mathrm{~h}$ every other day $(7370 \mathrm{gal} / \mathrm{acre})]$, the grower's normal irrigation regime at a depth of 12 inches $(30.5 \mathrm{~cm})$ for 2016 and 2017 on a commercial tomato farm; 1 gal $/$ acre $=9.3540$ L.ha ${ }^{-1}, 1 \mathrm{kPa}=0.01$ bar.

2) determine if the use of grafted plants is economically beneficial in conditions lacking soil-borne disease pressure. We hypothesize that those plants grafted onto 'Beaufort' rootstock will improve iWUE and yield at reduced irrigation because of its thin average root diameter and high specific root length (SRL) (Suchoff et al., 2017) as these RSM traits have been shown to improve water use efficiency in other crops (Comas et al., 2013; Ho et al., 2005; Huang and Eissenstat, 2000).

\section{Materials and methods}

Trial location. This study was conducted during Summer 2016 and 2017 on a commercial farm located in Alamance County, NC. Soil samples were taken before transplanting the first trial in 2016. Results indicated Cecil sandy loam soil type with $0.56 \%$ humic matter, cation exchange capacity of $10.1 \mathrm{meq} / 100 \mathrm{~cm}^{3}$, and $\mathrm{pH}$ of 6.3. The growers use a multibay hightunnel system [96 ft length $\times 24 \mathrm{ft}$ width $\times 13 \mathrm{ft}$ height (Pioneer Series high tunnel; Haygrove, Mount Joy, PA)] for all tomato production to reduce foliar disease incidence and extend harvests. Consequently, all plant water needs are met through drip irrigation. Planting within the high-tunnel system follows a 3-year rotation of tomato, cut flowers, and warm season cover crops. A mixture of winter wheat [Triticum aestivum (120 lb/acre sowing rate)] and crimson clover [Trifolium incarnatum (20 lb/acre sowing rate)] are grown during the fall and winter months and incorporated before bedding to meet the nutritional requirements for the crop.

Transplant production. All transplants were produced in an airinflated double-layer polyethylene greenhouse on the North Carolina State University (NCSU) campus in Raleigh. The rootstock cultivars BE [S. lycopersicum $\times S$. habrochaites (De Ruiter, St. Louis, MO)] and $S$ [S. lycopersicum (Rijk Zwaan, Salinas, CA)] were chosen as these two have significantly different root system morphologies (Suchoff et al., 2017). The BE root system has a much thinner average diameter, higher SRL, and shorter total root length than 'Shield'. The indeterminate heirloom cultivar CP (Johnny's Selected Seeds, Winslow, ME) is what the grower 




traditionally grows and, thus, used as both the scion for the two rootstocks and the nongrafted control. Seeds were started in 72-cell plug trays (T.O. Plastics, Clearwater, MN) filled with an all-purpose potting $\mathrm{mix}$ (Fafard ${ }^{\circledR}$ 4P Mix; Sun Gro ${ }^{\circledR}$ Horticulture, Agawam, MA). To account for its slower germination time, BE was planted $5 \mathrm{~d}$ before both $\mathrm{S}$ and $\mathrm{CP}$ scion material. The nongrafted $\mathrm{CP}$ were seeded $5 \mathrm{~d}$ after $S$ and scion CP to take into account the $5 \mathrm{~d}$ needed for graft healing.

Seedlings were grafted using the Japanese tube-graft method (Rivard and Louws, 2006). Grafts were healed in transparent plastic storage bins [26.5 inches length $\times 16$ inches height $\times 12.5$ inches width $\left(\right.$ Sterilite $^{\circledR}$, Townsend, MA)] where they received constant $100 \mu \mathrm{mol} \cdot \mathrm{m}^{-2} \cdot \mathrm{s}^{-1}$ of photosynthetically active radiation $\left[4 \times 6500{ }^{\circ} \mathrm{K}\right.$ (Spectralux ${ }^{\circledR} \mathrm{T} 5 \mathrm{HO}$ Fluorescent lamp; Sunlight Supply, Vancouver, WA)] in an indoor, controlled environment maintained at $78.8{ }^{\circ} \mathrm{F}$. High relative humidity $(>95 \%)$ was maintained by placing $\approx 1$ inch of water at the bottom of the bin with the flats raised above the water level and the bin tops taped shut. Each bin contained a single 72 -cell plug tray and three bins fit under each fluorescent lamp. Grafts were slowly acclimated to reduced humidity by gradually opening the tops until after $5 \mathrm{~d}$, when tops were removed. Healed grafts were of similar size to the nongrafted controls after the $5 \mathrm{~d}$ of healing and all plants were placed in a high tunnel on NCSU campus for $3 \mathrm{~d}$ to harden off before transplanting.

FIELD DESIGN. A strip-till system was used to prepare beds 1 month before transplanting. An established winter wheat and crimson clover was mowed and 3 -ft-wide beds were cultivated to a depth of 12 inches and then tilled to a depth of 6 inches. Compost was incorporated into each bed at a rate of $2352 \mathrm{ft}^{3}$ /acre of bed to supplement crop nutritional needs. Each high tunnel covers four rows spaced $5 \mathrm{ft}$ apart. To limit potential rainwater intrusion, the inner two rows of two conjoined high tunnels were used in the study. Drip tape with emitters spaced 8 inches apart [0.94 $\mathrm{gal} / \mathrm{min}$ per $100 \mathrm{ft}$ (8 Mil Lightweight $5 / 8$ inch Aqua-Traxx ${ }^{\circledR}$; Toro 

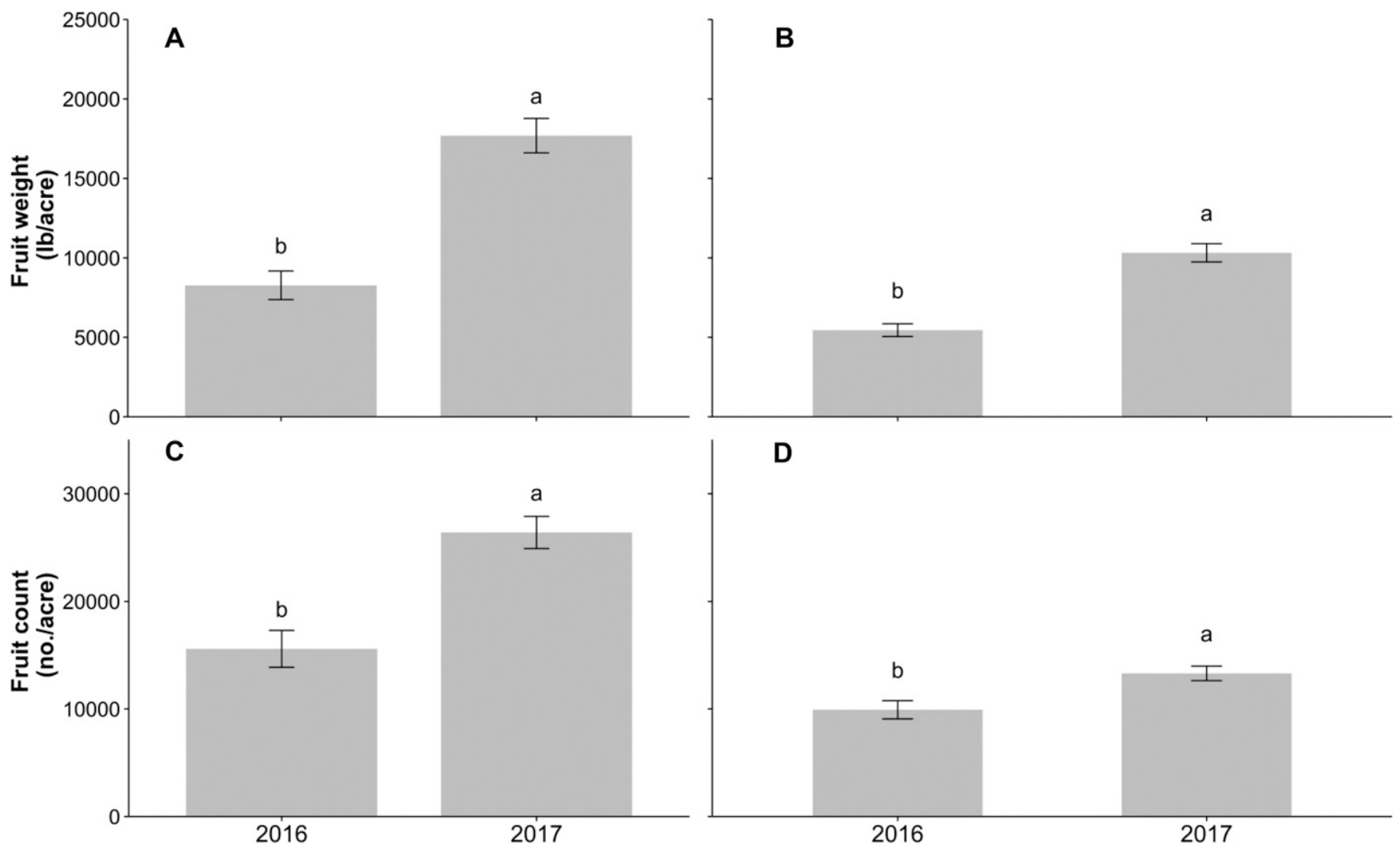

Fig. 3. Total cull fruit weight (A) and count (C) and grade B fruit weight (B) and count (D), \pm SE from high tunnel-grown tomato for 2016 and 2017 on a commercial tomato farm. Means with common letters within grade count or weight are not different (Tukey's honestly significant difference at $\alpha=0.05$ ) and represent the average of three graft treatments, two irrigation treatments, and four replication samples $(n=24$ data points for each mean). Grade B fruit are those with slight disfigurement but remain marketable, cull fruit are those that are rendered unmarketable because of crack or pest damage or have a diameter less than 2 inches $(5.1 \mathrm{~cm}) ; 1 \mathrm{lb} / \mathrm{acre}=1.1209 \mathrm{~kg} \cdot \mathrm{ha}^{-1}, 1 \mathrm{fruit} / \mathrm{acre}=2.4711 \mathrm{fruit} / \mathrm{ha}$.

Co., El Cajon, CA)] was placed on top of the soil and 4 -ft-wide black woven groundcover was placed over each bed. An 8-inch-deep trench was dug across the middle of each bed and a 0.75 -inch-thick wooden board was placed in the trench. This board reduced the lateral movement of water within the soil profile between the two sections. Drip tape at this midpoint was cut and the two sections were randomly assigned an irrigation treatment. The study was arranged in a split-plot design with the whole plot arranged in a randomized complete block design with four blocks. Irrigation treatments (whole plot) were either $100 \%$ of the grower's normal irrigation regime $[3 \mathrm{~h}$ every other day $(14,741 \mathrm{gal} /$ acre $)]$ or $50 \%$ [ $1.5 \mathrm{~h}$ every other day (7370 gal/acre)]. Each half block was randomly assigned an irrigation treatment. A dual line irrigation timer (Aquedue Duplo ${ }^{\circledR}$ Evolution; Claber $^{\circledR}$, Geneva, IL) allowed for independent irrigation of each half block at the appropriate time. Two headers (1.5 inch Blue Stripe ${ }^{\circledR}$ Oval Hosing, Toro Co.) were connected to the timer, one for each irrigation treatment, and ran along the entrance of each high tunnel. Drip lines were connected to the appropriate header depending on the assigned irrigation treatment. Mainline tubing (1 inch Blue Stripe ${ }^{\circledR}$ Poly Tubing, Toro Co.) was attached to the appropriate header and ran down the half of the block where it was connected to the cut drip tape at the midpoint. Total applied irrigation in 2016 was 434,816 and $810,739 \mathrm{gal} /$ acre for $50 \%$ and $100 \%$ irrigation treatments, respectively. In $2017,383,240$ and $766,482 \mathrm{gal} /$ acre was applied to the $50 \%$ and $100 \%$ irrigation treatments, respectively.

The three graft treatments (splitplot) were randomly assigned within each whole plot. Split plots comprised 10 plants spaced 18 inches apart. Transplanting occurred on 22 Apr. 2016 and 14 Apr. 2017. In 2016, all transplants received $100 \%$ irrigation regime for the first week until established. Plants were pruned once in 2 weeks after transplanted to remove suckers below the first flower truss, and a single leader was vertically trained along a wire fence with tie ribbon once per week.

Data collection. Matric water potential sensors (MPS-6; METER Group, Pullman, WA) were placed randomly within each whole-plot replication $(n=8)$ at a depth of $\approx 12$ inches, and soil matric water potential readings were taken every hour and stored in a data logger (EM50, METER Group).

Plant height was measured from the internal third, fifth, and seventh plants within a plot. In 2016, measurements started $7 \mathrm{~d}$ after transplant (DAT) and were collected weekly until 42 DAT, at which point fruit started to develop. Plant height measurements in 2017 were collected in the same fashion but were extended 


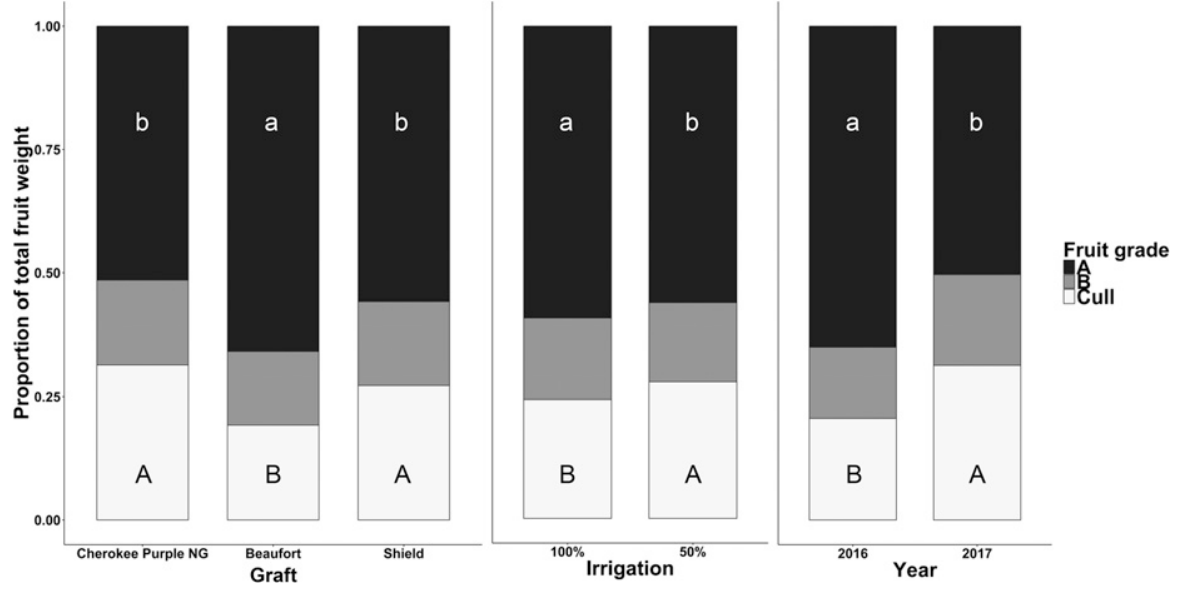

Fig. 4. Graft, irrigation, and year main effects on fruit grade as a proportion of total fruit weight for high tunnel-grown tomato from a commercial tomato farm. Means with common letters within the same grade and main effect are not different (Tukey's honestly significant difference at $\alpha=0.05$ ) and represent the average of two irrigation treatments, four replications and two repeated experiments for graft treatment effect ( $n=16$ data points for each mean), three graft treatments, four replications, and two repeated experiments for irrigation treatment effect ( $n=24$ data points for each mean) and three graft treatments, two irrigation treatments, and four replications for year main effect $(n=24$ data points for each mean). Tomato cultivar Cherokee Purple was grafted onto either Beaufort or Shield rootstocks or left nongrafted (NG) as a control. Grade A fruit are those free of blemishes or disfigurement and are larger than 2 inches $(5.1 \mathrm{~cm})$ in diameter, grade $B$ are fruit with slight disfigurement but remain marketable, and cull fruit are those not marketable because of cracking or pest damage or have a diameter less than 2 inches. Irrigation treatments were either $100 \%$ [ $3 \mathrm{~h}$ every other day $(14,741 \mathrm{gal} / \mathrm{acre})]$ or $50 \%$ [ $1.5 \mathrm{~h}$ every other day $(7370 \mathrm{gal} / \mathrm{acre})]$ of the grower's normal irrigation regime; $1 \mathrm{gal} / \mathrm{acre}=9.3540 \mathrm{~L} \cdot \mathrm{ha}^{-1}$.

until 70 DAT because height results from 2016 did not appear to plateau at 42 DAT.

Harvest began 59 DAT in 2016 and 63 DAT in 2017. Harvests occurred twice per week for 8 weeks in 2016 ( $n=16$ harvests) and 6 weeks in 2017 ( $n=12$ harvests). All fruit were harvested within a plot once they reached the turning stage [between $10 \%$ and $30 \%$ of the fruit showing pink/red coloration (U.S. Department of Agriculture, 2005)]. Fruit were graded based on the grower's standards: grade A fruit are those free of blemishes or disfigurement and are larger than 2 inches in diameter, grade B fruit are those with slight blemishes, disfigurement, but are still marketable, and culls are those fruit rendered unmarketable because of cracking, disease, or pest injury (Fig. 1). Fruit in each grade were counted and weighed. Total fruit weight was divided by total fruit count for each grade at the end of the season to give an average individual fruit weight for grades B and A. Proportions of total harvest based on grade were calculated at the end of the season. iWUE (pounds per gallon) was calculated for grade A fruit and all marketable fruit (grade A and grade B combined) by dividing the total yields at the end of the season by the total volume of water applied.

In 2017, potato aphid (Macrosiphum euphorbia) infestation in the first 2 months of growth was significant enough to warrant application of a contact insecticide via foliar spray at a rate of $1.81 \mathrm{oz} / 100 \mathrm{gal}$ a.i. $\left(\right.$ Mycotrol $^{\circledR}$ ESO; BioWorks ${ }^{\circledR}$, Victor, NY). Application effectively managed the pest population for the remainder of the season.

At the end of each season, six random plants were uprooted and root systems checked for any disease or nodulation caused by root knot nematodes (Meloidogyne sp.); no nodulation or disease was observed.

Data anAlysis. All data were analyzed using the GLIMMIX procedure in SAS (version 9.4; SAS Institute, Cary, NC). Irrigation, graft, and year were analyzed as fixed effects with block and irrigation $\times$ block as random. Fruit count and proportions of total harvest based on grade were modeled using a negative binomial and beta distribution, respectively, with the canonical link functions. Pearson chi-squared statistics divided by the $\mathrm{df}(\varphi)$ were checked for overdispersion and distribution goodnessof-fit. Cumulative yield over time for grades $\mathrm{A}$ and $\mathrm{B}$ and plant height were analyzed as repeated measures with a heterogenous first-order autoregressive covariance structure. Because both height measurements and number of harvests differed by year, these data were analyzed separately by year. Residual plots were checked for potential outliers and heteroscedasticity. Tukey's honestly significant difference test was used to compare means when appropriate. Finally, we ran an economic assessment to compare the financial feasibility of grafting using production values from the grower and those published by Rysin and Louws (2015).

\section{Results}

Matric water potential in the $50 \%$ irrigation treatment was more negative than the $100 \%$ treatment in both 2016 and 2017 (Fig. 2). In 2016, these differences became more pronounced midway through July and through the rest of the season. In 2017, these differences were observed earlier in the season, toward the end of May, and remained until the end of the study.

Plant height. The interaction of graft and DAT was significant in both 2016 and 2017 for plant height; slight differences (less than 2 inches) were observed early in the season, but these differences were not observed after 35 DAT (data not shown).

YIELD. None of the first-order interactions with year or the secondorder interactions were significant for any yield response variables (Table 1 ). Average fruit weight for grades A and $B$ were unaffected by any treatments in this study. Total weight and count for culls and grade B fruit were different between years; values for both grades were significantly higher in 2017 than in 2016 (Fig. 3A-D). The proportion of total fruit weight composed of grade A and culls was affected by the main effects of graft, irrigation, and year (Table 1$)$. S and CP had a higher proportion of their total fruit weight composed of culls 


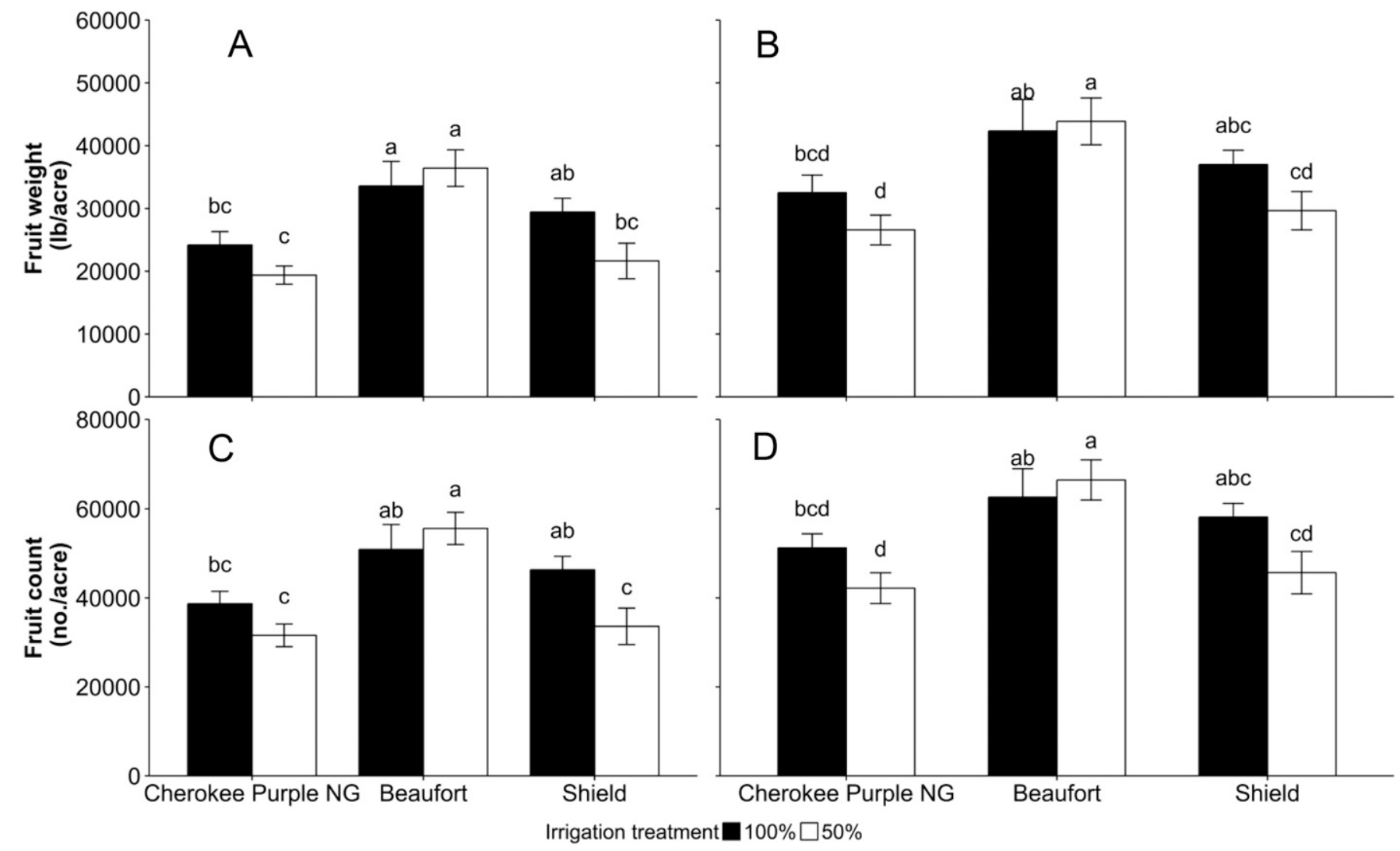

Fig. 5. Total grade A fruit weight $(A)$ and count $(C)$ and marketable fruit weight (B) and count (D), $\pm S E$ from high tunnelgrown tomato receiving $100 \%$ [ $3 \mathrm{~h}$ every other day $(14,741 \mathrm{gal} / \mathrm{acre})]$ or $50 \%$ [ $1.5 \mathrm{~h}$ every other day (7370 gal/acre)] of the grower's normal irrigation regime. Means with common letters within a grade are not different (Tukey's honestly significant difference at $\alpha=0.05)$ and represent the average of four replications and two repeated experiments $(n=8$ data points for each mean). Tomato cultivar Cherokee Purple was grafted onto either Beaufort or Shield rootstocks or left nongrafted (NG) as a control. Grade A fruit are those free of blemishes or disfigurement and are larger than 2 inches $(5.1 \mathrm{~cm})$ in diameter. Marketable fruit are the combination of grade $A$ and grade $B$ fruit, the latter being fruit with slight disfigurement but remain marketable; $1 \mathrm{gal} /$ acre $=9.3540 \mathrm{~L} \cdot \mathrm{ha}^{-1}, 1 \mathrm{lb} /$ acre $=1.1209 \mathrm{~kg} \cdot \mathrm{ha}^{-1}, 1 \mathrm{fruit} / \mathrm{acre}=2.4711 \mathrm{fruit} / \mathrm{ha}$.

compared with $\mathrm{BE}$, whereas the latter had a higher proportion of grade $\mathrm{A}$ fruit compared with $S$ and CP (Fig. 4 ). The $100 \%$ irrigation treatment resulted in a higher proportion of grade A fruit and concurrent reduction in proportion culls compared with the 50\% treatment (Fig. 4). Finally, 2016 had a higher proportion of grade A fruit and less culls than 2017 (Fig. 4).

The graft $\times$ irrigation interaction was significant for grade A count and weight as well as marketable fruit count and weight (Table 1). At 100\% irrigation there was no difference in grade A fruit count among graft treatments (Fig. 5C); however, grade A fruit weight was higher in $\mathrm{B}(33,585.5$ lb/acre) compared with CP $(24,184.5$ lb/acre) (Fig. 5A). No differences were observed in marketable fruit count or weight among graft treatments at $100 \%$ irrigation (Fig. 5B and $\mathrm{D})$. At $50 \%$ irrigation, grade $\mathrm{A}$

Table 2. Repeated measures analysis of cumulative tomato yield of grades $A$ and $B$ fruit from high tunnel-grown grafted and nongrafted tomato receiving two different irrigation treatments for 2016 and 2017.

\begin{tabular}{|c|c|c|c|c|c|c|}
\hline \multirow[b]{2}{*}{ Effect } & \multicolumn{3}{|c|}{$2016^{z}$} & \multicolumn{3}{|c|}{2017} \\
\hline & df & Grade $\mathrm{B}$ wt $^{\mathrm{y}}$ & Grade $A w t^{y}$ & df & Grade B wt & Grade A wt \\
\hline $\operatorname{Graft}(\mathrm{G})^{\mathrm{x}}$ & 2 & NS & NS & 2 & NS & NS \\
\hline Irrigation $(\mathrm{I})^{\mathrm{w}}$ & 1 & NS & NS & 1 & NS & NS \\
\hline $\mathrm{G} \times \mathrm{I}$ & 2 & NS & NS & 2 & NS & NS \\
\hline Harvest $(\mathrm{H})^{\mathrm{v}}$ & 11 & $* * *$ & $* * *$ & 9 & $* * *$ & $* * *$ \\
\hline $\mathrm{G} \times \mathrm{H}$ & 22 & NS & * & 18 & NS & $* * *$ \\
\hline $\mathrm{I} \times \mathrm{H}$ & 11 & NS & NS & 9 & NS & NS \\
\hline $\mathrm{G} \times \mathrm{I} \times \mathrm{H}$ & 22 & NS & NS & 18 & NS & NS \\
\hline
\end{tabular}

${ }^{\mathrm{z}}$ Years were analyzed separately because of different lengths of data collection for harvests.

y Fruit grades based on the grower's specifications. Grade A fruit are those with no blemishes or disfigurement large than 2 inches $(5.1 \mathrm{~cm})$ in diameter. Grade B fruit are those with slight disfigurement, but still marketable, and culls are any nonmarketable fruit.

'Graft treatment comprises nongrafted 'Cherokee Purple' grower control, 'Cherokee Purple' grafted onto 'Beaufort' rootstock, and 'Cherokee Purple' grafted onto 'Shield' rootstock.

wIrrigration treatments represent $100 \%$ [ $3 \mathrm{~h}$ every other day $(14,741 \mathrm{gal} / \mathrm{acre})]$ or $50 \%$ [ $1.5 \mathrm{~h}$ every other day $(7370 \mathrm{gal} / \mathrm{acre})]$ of the grower's normal irrigation regime; $1 \mathrm{gal} / \mathrm{acre}=9.3540 \mathrm{~L} \cdot \mathrm{ha}^{-1}$.

${ }^{v}$ Harvests occurred twice per week for 8 and 6 weeks in 2016 and 2017 , respectively. Ns, ${ }^{*},{ }^{* *},{ }^{* *}$ Denote nonsignificant at $P \leq 0.05$, significant at $P \leq 0.05,0.01,0.001$, respectively.

fruit count was higher in $\mathrm{BE}$ $(55,612$ fruit/acre) than both $S$ $(33,614$ fruit/acre $)$ and CP
$(31,581$ fruit/acre) (Fig. 5C). Consequently, grade A fruit weight followed the same trend with BE yields 


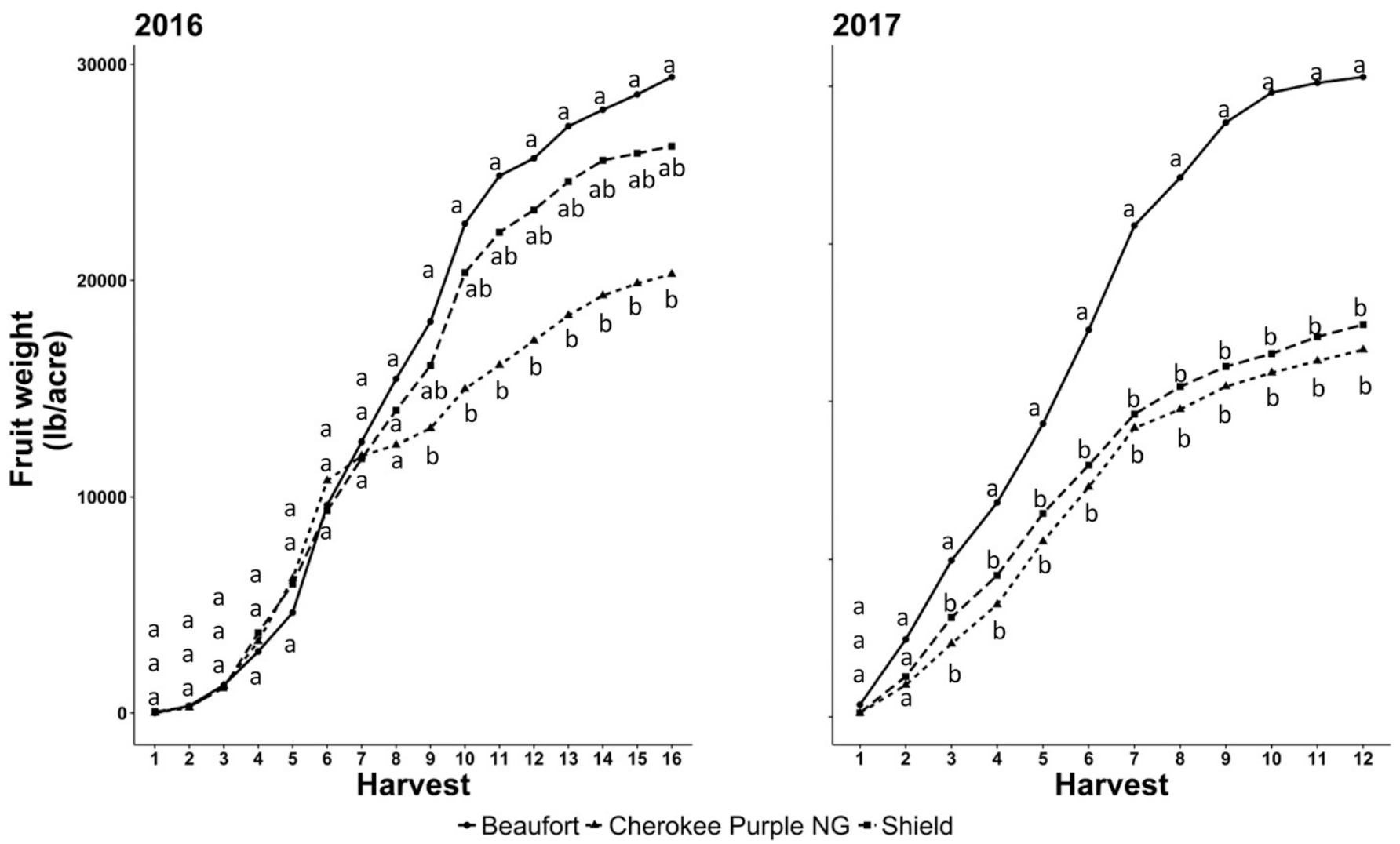

Fig. 6. Repeated measures analysis of cumulative yield of grade A fruit from high tunnel-grown tomato in 2016 and 2017. Means with common letters within a grade are not different (Tukey's honestly significant difference at $\alpha=0.05$ ) and represent the average of four replications and two irrigation treatments $(n=8$ data points for each mean). Tomato cultivar Cherokee Purple was grafted onto either Beaufort or Shield rootstocks or left nongrafted (NG) as a control. Grade A fruit are those free of blemishes or disfigurement and are larger than 2 inches $(5.1 \mathrm{~cm})$ in diameter; $1 \mathrm{lb} / \mathrm{acre}=1.1209 \mathrm{~kg} \cdot \mathrm{ha}^{-1}$.

$(36,424.9 \mathrm{lb} / \mathrm{acre})$ being significantly higher than $S(21,648.6 \mathrm{lb} /$ acre) and $\mathrm{CP}(19,388.6 \mathrm{lb} / \mathrm{acre})$ (Fig. 5A). These trends were also observed in marketable fruit weight and count; at $100 \%$ irrigation, no differences were observed among the graft treatments, but at $50 \%$ $\mathrm{BE}$, yielded significantly higher fruit count and weight (Fig. 5B and D). Furthermore, BE yielded higher grade $\mathrm{A}$ and marketable fruit weight and count at $50 \%$ irrigation than $\mathrm{CP}$ at $100 \%$ irrigation (Fig. 5A-D). In $S$ and $\mathrm{CP}$, there was a trend toward reduced fruit count and weight with a reduction in irrigation; however, this trend was not observed in BE.

The longitudinal analysis of $\mathrm{cu}^{-}$ mulative yield resulted in a significant graft $\times$ harvest interaction for grade $\mathrm{A}$ fruit production in 2016 and 2017 (Table 2). In 2016, no differences were observed among the graft treatments over the first eight harvests; however, starting at harvest nine until the last harvest, $\mathrm{BE}$ yielded significantly more than $\mathrm{CP}$ with S intermediate of the two (Fig. $6)$. In 2017, differences were observed earlier in the harvest. Starting at harvest three, BE consistently yielded more than both $C P$ and $S$.

iWUE for both grade $A$ and marketable fruit was affected by the graft $\times$ irrigation interaction (Table 1 ). At $100 \%$ irrigation, there were no differences in iWUE among the graft treatments for grade A or marketable fruit (Fig. 7A and B). iWUE was higher for the $50 \%$ irrigation treatment than the $100 \%$ treatment. At the $50 \%$ irrigation treatment, $\mathrm{BE}$ had significantly higher iWUE for both grades than $S$ and $C P$. iWUE for BE at $50 \%$ irrigation, regardless of fruit grade, was nearly three times higher than that of $\mathrm{CP}$ at the $100 \%$ irrigation treatment. The main effect of year significantly affected marketable fruit iWUE (Table 1); 2017 had an overall higher iWUE compared with 2016.

ECONOMIC ASSESSMENT. Using the values from Rysin and Louws (2015) of $\$ 0.12$ and $\$ 1.02$ per nongrafted and grafted transplant, respectively, an additional $\$ 5227.2$ per acre would need to be invested for the utilization of grafted plants (Table 3 ). Furthermore, because of the significantly higher grade A fruit production of $\mathrm{BE}$ even at $50 \%$ irrigation, harvest labor would increase by $\$ 1713.65$ per acre. Even with these additional investments, net revenue would increase by $\$ 35,900.41$ per acre when using $\mathrm{BE}$ at $50 \%$ irrigation compared with $\mathrm{CP}$ at $100 \%$ irrigation, amounting to a $44.6 \%$ increase in net revenue.

\section{Discussion}

Although the initial implementation of grafting was for the management of soil-borne pathogens (Kubota et al., 2008), additional rootstock-derived benefits exist outside of disease resistance (Djidonou et al., 2013b; Ntatsi et al., 2017; Schwarz et al., 2010). Here we show that in the absence of disease pressure, grafting onto BE significantly improved iWUE and yields at $50 \%$ of the grower's normal irrigation rate (Figs. 5A-D, 


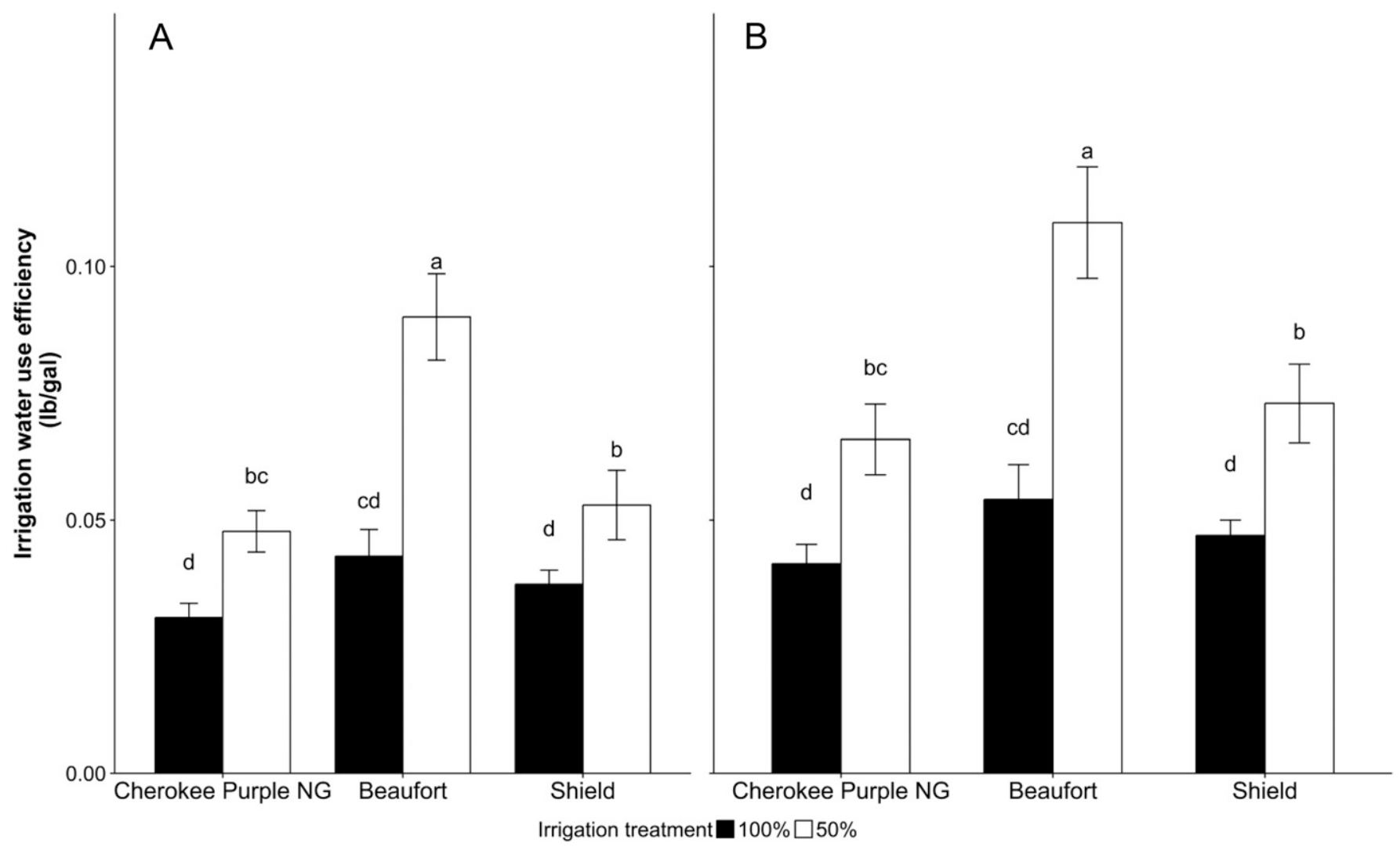

Fig. 7. Irrigation water use efficiency for grade A (A) and marketable fruit (B), \pm SE from high tunnel-grown tomato receiving $100 \%$ [ $3 \mathrm{~h}$ every other day $(14,741 \mathrm{gal} / \mathrm{acre})]$ or $50 \%$ [ $1.5 \mathrm{~h}$ every other day $(7370 \mathrm{gal} / \mathrm{acre})]$ of the grower's normal irrigation regime. Means with common letters within a grade are not different (Tukey's honestly significant difference; $\alpha=0.05)$ and represent the average of four replications and two repeated experiments $(n=8$ data points for each mean). Tomato cultivar Cherokee Purple was grafted onto either Beaufort' or Shield rootstocks or left nongrafted (NG) as a control. Grade A fruit represent those fruit free of blemishes or disfigurement and are larger than 2 inches $(5.1 \mathrm{~cm})$ in diameter. Marketable fruit are the combination of grade $A$ and grade $B$ fruit, the latter being fruit with slight disfigurement but remain marketable; 1 gal $/$ acre $=$ $9.3540 \mathrm{~L} \cdot \mathrm{ha}^{-1}, 1 \mathrm{lb} / \mathrm{gal}=0.1198 \mathrm{~kg} \cdot \mathrm{L}^{-1}$.

Table 3. Economic assessment of high tunnel-grown nongrafted 'Cherokee Purple' tomato at full irrigation vs 'Cherokee Purple' grafted onto 'Beaufort' rootstock at reduced irrigation based on the average of 2016 and 2017 grade A yield results. ${ }^{\text {' }}$

\begin{tabular}{lcr}
\hline Variable $^{\mathrm{y}}$ & $\begin{array}{c}\text { Cherokee Purple } \\
\text { nongrafted: } \mathbf{1 0 0 \%} \text { irrigation }^{\mathbf{x}}\end{array}$ & $\begin{array}{c}\text { Cherokee Purple grafted } \\
\text { onto Beaufort: 50\% irrigation }^{\mathbf{x}}\end{array}$ \\
\hline Number of transplants (plants/acre) & 5,808 & 5,808 \\
Price of transplant $(\$ /$ plant) & 0.12 & 1.02 \\
Cost of transplants $(\$ /$ acre) & 696.96 & $5,924.16$ \\
Average yield of grade A (lb/acre) & $24,184.51$ & $36,424.87$ \\
Labor cost $(\$ /$ lb) & 0.14 & 0.14 \\
Harvest cost $(\$ /$ acre $)$ & $3,385.83$ & $5,099.48$ \\
Sale price $(\$ / \mathrm{lb})$ & 3.50 & 3.50 \\
Gross revenue $(\$ /$ acre $)$ & $84,645.79$ & $127,487.05$ \\
Net revenue $(\$ /$ acre $)$ & $80,563.00$ & $116,463.41$ \\
\hline
\end{tabular}

${ }^{\mathrm{z}}$ Grade A fruit are those with no blemishes or disfigurement large than 2 inches $(5.1 \mathrm{~cm})$ in diameter.

${ }^{y}$ Price of transplants derived from Rysin and Louws (2015). Values for labor and sales price specified by the grower; 1 plant $/$ acre $=2.4711$ plant $/$ ha, $\$ 1 /$ acre $=\$ 2.4711 /$ ha, $1 \mathrm{lb} /$ acre $=1.1209 \mathrm{~kg} \cdot \mathrm{ha}^{-1}, \$ 1 / \mathrm{lb}=\$ 2.2046 / \mathrm{kg}$.

${ }^{\mathrm{x}}$ Irrigation treatments represent $100 \%$ [ 3 h every other day ( 14,741 gal/acre $)$ ] or $50 \%$ [ 1.5 h every other day ( 7370 gal/acre $)$ ] of the grower's normal irrigation regime; $1 \mathrm{gal} /$ acre $=9.3540 \mathrm{~L} \cdot \mathrm{ha}^{-1}$.

$7 \mathrm{~A}$ and $\mathrm{B})$. These results are in agreement with Djidonou et al. (2013b) who found that grafting the determinate cultivar Florida 47 onto BE improved iWUE in open-field production. In their study, the authors demonstrated improved iWUE regardless of irrigation regime. We only observed iWUE differences at the $50 \%$ irrigation regime. The discrepancies between studies may be because our study used an indeterminate tomato cultivar and conducted the study under protection from rain. The authors also found that grafting onto 'Multifort' rootstock improved iWUE. Both 'Multifort' and BE are interspecific 
hybrids and were shown to have similar RSM (Suchoff et al., 2017). In our study, 'Shield' was chosen as its root system is composed of much thicker, longer roots, with a lower SRL compared with BE (Suchoff et al., 2017). Crops with thin average root diameter and high SRL show an increase in hydraulic conductivity (Huang and Eissenstat, 2000). Furthermore, high SRL allows for root system development with minimized photosynthate investment compared with root systems with low SRL (Eissenstat, 1992). The improved yield and iWUE observed here and by Djidonou et al. (2013b) may be due to a thinner root system in BE that can more easily absorb and use available water and, because of high SRL, can increase root soil exploration with minimal photosynthate investment.

Differences in plant height were observed among graft treatments in both years of the study; however, no overall trend was seen nor do these differences explain yield or iWUE differences among graft treatments. Khah et al. (2006) found no differences in plant height among grafted tomato on different rootstocks compared with nongrafted and selfgrafted controls when grown in greenhouse conditions; however, when grown in open-field conditions, differences were observed. The more favorable environment experienced by plants grown in protected culture may reduce the plant height-diminishing stresses compared with openfield production.

Higher cull and grade B fruit were produced in 2017 compared with 2016 (Fig. 3A-D). These yearly differences are most likely due to the potato aphid infestation that occurred early in 2017; prior work has demonstrated a reduction in tomato fruit quality due to potato aphid infestation (Walgenbach, 1997). We observed a higher amount of damage and disfigurement early in the 2017 harvest season which coincided with potato aphid infestation and the amount of this damaged fruit reduced later in the season following insecticide application.

Grafting onto BE increased the proportion of grade A fruit produced (Fig. 4). Di Gioia et al. (2010) and Leonardi and Giuffrida (2006) found that $\mathrm{BE}$ increased marketable fruit production in conditions lacking any significant disease pressure. This increase in marketable fruit production may be due to improved nutrient uptake when using $\mathrm{BE}$ as a rootstock (Leonardi and Giuffrida, 2006).

Marketable yield was defined as the combined weight of grade A and $\mathrm{B}$ fruit and was not different among the three graft treatments at $100 \%$ irrigation (Fig. 5B), although the results followed a similar trend to grade A fruit production (Fig. 5A). We attribute this to the added variability when combining grade $B$ fruit to grade $\mathrm{A}$ as there was no significant interaction of graft and irrigation treatments on grade $\mathrm{B}$ production (Table 1). Nevertheless, grade B fruit yield made up a smaller proportion of total yield (Fig. 4) and would not contribute as significantly to net revenue as grade A fruit.

The use of grafted tomato requires a high initial investment. In situations where disease pressure is significant, using grafted tomato with resistant rootstocks has the potential to offset that initial investment; however, net returns are dependent on disease pressure and market prices (Djidonou et al., 2013a; Rysin and Louws, 2015). Here we show that grafting 'Cherokee Purple' onto BE increased net revenue by $44.6 \%$ while reducing the water applied by $50 \%$ (Table 3). This reduction amounts to a saving of 375,923 and $383,242 \mathrm{gal} /$ acre in 2016 and 2017, respectively. Irrigation for this farm comes from an on-site pond and, as such, water is not an annually limited resource. In areas where water is less plentiful and growers must pay for irrigation water, such as California, the increased iWUE when using BE as a rootstock has the potential to further reduce initial transplant investment costs by decreasing irrigation expenses.

\section{Conclusion}

This study is one of the first to demonstrate the ability of specific tomato rootstocks to improve iWUE in an on-farm situation. With the addition of improved iWUE, rootstock-scion combinations can be selected to meet market demand, disease pressure, and limited water availability. This improved iWUE may be due to differences in RSM (Suchoff et al., 2017). Future work is needed to determine the specific morphological or physiological aspects of the $\mathrm{BE}$ rootstock root system that improve water use efficiency under limiting conditions. This information will allow for further rootstock selection and aid in our understanding of plant-water relations.

\section{Literature cited}

Blum, A. 2005. Drought resistance, water-use efficiency, and yield potentialAre they compatible, dissonant, or mutually exclusive? Austral. J. Agr. Res. 56:1159-1168.

Comas, L.H., S.R. Becker, V.C. Von Mark, P.F. Byrne, and D.A. Dierig. 2013. Root traits contributing to plant productivity under drought. Front. Plant Sci. $4: 442$.

De Pascale, S., L. Dalla Costa, S. Vallone, G. Barbieri, and A. Maggio. 2011. Increasing water use efficiency in vegetable crop production: From plant to irrigation systems efficiency. HortTechnology 21:301308 .

Di Gioia, F., F. Serio, D. Buttaro, O. Ayala, and P. Santamaria. 2010. Influence of rootstock on vegetative growth, fruit yield and quality in 'Cuore di Bue', an heirloom tomato. J. Hort. Sci. Biotechnol. 85:477-482.

Djidonou, D., Z. Gao, and X. Zhao. 2013a. Economic analysis of grafted tomato production in sandy soils in north Florida. Hort Technology 23:613-621.

Djidonou, D., X. Zhao, E.H. Simonne, K. E. Koch, and J.E. Erickson. 2013b. Yield, water-, and nitrogen-use efficiency in field-grown, grafted tomatoes. HortScience 48:485-492.

Eissenstat, D.M. 1992. Costs and benefits of constructing roots of small diameter. J. Plant Nutr. 15:763-782.

Evans, R.G. and E.J. Sadler. 2008. Methods and technologies to improve efficiency of water use. Water Resources Res. 44:1-15.

Food and Agriculture Organization of the United Nations. 2002. Crops and drops: Making the best use of water for agriculture. Natural Resources Environ. Dept., FAO, Rome, Italy.

Gewin, V. 2010. Food: An underground revolution. Nature 466:552-553.

Henry, A., V.R.P. Gowda, R.O. Torres, K.L. McNally, and R. Serraj. 2011. Variation in root system architecture and drought response in rice (Oryza sativa): Phenotyping of the OryzaSNP panel in rainfed lowland fields. Field Crops Res. 120:205-214. 
Ho, M.D., J.C. Rosas, K.M. Brown, and J.P. Lynch. 2005. Root architectural tradeoffs for water and phosphorus acquisition. Funct. Plant Biol. 32:737-748.

Huang, B. and D.M. Eissenstat. 2000. Linking hydraulic conductivity to anatomy in plants that vary in specific root length. J. Amer. Soc. Hort. Sci. 125:260264.

Khah, E.M., E. Kakava, A. Mavromatis, D. Chachalis, and C. Goulas. 2006. Effect of grafting on growth and yield of tomato (Lycospersicon esculentum Mill.) in greenhouse and open-field. J. Appl. Hort. 8: 3-7.

Kubota, C., M.A. McClure, N. KokalisBurelle, M.G. Bausher, and E.N. Rosskopf. 2008. Vegetable grafting: History, use, and current technology status in North America. HortScience 43:1664-1669.

Leonardi, C. and F. Giuffrida. 2006. Variation of plant growth and macronutrient uptake in grafted tomatoes and eggplants on three different rootstocks. Eur. J. Hort. Sci. 71:97-101.

Louws, F.J., C.L. Rivard, and C. Kubota. 2010. Grafting fruiting vegetables to manage soilborne pathogens, foliar pathogens, arthropods and weeds. Scientia Hort. 127:127-146.

Lynch, J.P. 2007. Roots of the second green revolution. Austral. J. Bot. 55:493512 .

Malamy, J.E. 2005. Intrinsic and environmental response pathways that regulate root system architecture. Plant Cell Environ. 28:67-77.
Mickelbart, M.V., P.M. Hasegawa, and J. Bailey-Serres. 2015. Genetic mechanisms of abiotic stress tolerance that translate to crop yield stability. Natl. Rev. Genet. 16:237-251.

Molden, D. (ed.). 2007. Water for food, water for life: A comprehensive assessment of water management in agriculture. Intl. Water Mgt. Inst., London, UK.

Ntatsi, G., D. Savvas, V. Papasotiropoulos, A. Katsileros, R.M. Zrenner, D.K. Hincha, E. Zuther, and D. Schwarz. 2017. Rootstock sub-optimal temperature tolerance determines transcriptomic responses after long-term root cooling in rootstocks and scions of grafted tomato plants. Front. Plant Sci. 8:911.

Pennisi, E. 2008. The blue revolution, drop by drop, gene by gene. Science 320:171-173.

Rivard, C.L. and F.J. Louws. 2006. Grafting for disease resistance in heirloom tomatoes. North Carolina Coop. Ext. Serv. Bul. Agr. 675.

Rysin, O. and F.J. Louws. 2015. Decision tool for growers to evaluate economic impact of grafting technology adoption: An application to open-field conventional tomato production. HortTechnology 25:132-138.

Schaible, G.D. and M.P. Aillery. 2012. Water conservation in irrigated agriculture: Trends and challenges in the face of emerging demands. 18 Mar. 2018. <https://www.ers.usda.gov/webdocs/ publications/44696/30955_eib99_ reportsummary.pdf? $\mathrm{v}=41744>$.

Schwarz, D., Y. Rouphael, G. Colla, and J. H. Venema. 2010. Grafting as a tool to improve tolerance of vegetables to abiotic stresses: Thermal stress, water stress and organic pollutants. Scientia Hort. 127:162171.

Suchoff, D.H., C.C. Gunter, and F.J. Louws. 2017. Comparative analysis of root system morphology in tomato rootstocks. HortTechnology 27:319-324.

U.S. Department of Agriculture. 2005. Tomatoes: Shipping points and market inspection instructions. Agricultural marketing service. Fruit and vegetable programs fresh products branch. 18 Mar. 2018. <https://www.ams.usda.gov/ sites/default/files/media/Tomato_ Inspection_Instructions $\% 5 \mathrm{~B} 1 \% 5 \mathrm{D}$.pdf $>$.

Walgenbach, J.F. 1997. Effect of potato aphid (Homoptera: Aphididae) on yield, quality, and economics of staked-tomato production. J. Econ. Entomol. 90:9961004.

Wasson, A.P., R.A. Richards, R. Chatrath, S.C. Misra, S.V. Prasad, and G.J. Rebetzke. 2012. Traits and selection strategies to improve root systems and water uptake in water-limited wheat crops. J. Expt. Bot. 63:3485-3498. 